\title{
NEW APPROACHES TO BANKING BUSINESS MODELS IN THE DIGITAL ECONOMY
}

\author{
D'yakonova I.I., Dr of Science (Economics), Professor \\ Sumy State University \\ 2, Rymskogo-Korsakova st., 40007 Sumy, Ukraine \\ i.diakonova@uabs.sumdu.edu.ua \\ Pakhnenko O.M., PhD in Economics, Associate Professor \\ Sumy State University \\ 2, Rymskogo-Korsakova st., 40007 Sumy, Ukraine \\ o.pakhnenko@uabs.sumdu.edu.ua
}

Shevchenko L.M., Master student, International Economic Relations Department

Sumy State University

2, Rymskogo-Korsakova st., 40007 Sumy, Ukraine

Lilya.sheva76@gmail.com

The factors of the post-crisis development of the world banking system, the strengthening of the role of information technology in all industries, the increasing role of innovative Fintech intermediaries in the banking market encourage the management of banks to revise traditional business models and to form new approaches to managing the modern bank. In the article the authors aimed to investigate the impact of digitization on the choice of banking business model and the development of algorithm for estimating a bank's business model.

Traditionally banks choose one of five business models: lending, high leverage, investment, fee, margin. Most operating banks opt for traditional models because the business environment requires it. However, maintaining the bank's competitiveness, enhancing its efficiency and resilience to financial imbalances is possible by building an innovative business model that takes into account the modern diffusion of information technology and the functioning of FinTech companies as an alternative to traditional banking business. Although nobody knows yet what will replace the current business model, there are currently three approaches to assimilating FinTech in banking: the Financial Control Center, Banking-as-a-Service, the Niche Bank. The choice of the banking business model and its transformation should be accompanied by an assessment of the bank's business model.

Thus, an important component of banking management in an unstable environment is the analysis of the business model of the bank and its transformation in order to minimize the impact of possible negative effects of financial crises on the performance of the bank. The proposed algorithm for estimating a bank's business model includes 6 stages: preliminary assessment of the main components of the bank's business model; assessment of the business environment of the bank; stress testing of the viability of the bank's business model; evaluation of the bank's strategy; identification of key vulnerabilities to which the bank's business model is prone or likely to be vulnerable; and justification of the results and formation of effective conclusions.

Keywords: banks, banking business model, banking management, digital economy, business model innovation.

DOI: $10.21272 / 1817-9215.2019 .1-12$

\section{INTRODUCTION}

In recent decades, the global banking market has undergone significant transformations. Banking market leaders, as well as global financial centres, have shifted from Europe to Asia. In addition, inclusive digitalization has a significant impact on the formation of business models of modern banks. Sustainable business model innovation is increasingly seen as a lever for changing systems for sustainability in businesses and industries. Banks play a unique intermediary role in sustainable development, but also have a difficult position after the 2008 financial crisis. Together, the factors of the post-crisis development of the world banking system, the strengthening of the role of information technology in all industries, the increasing role of innovative Fintech intermediaries in the banking market encourage the management of banks to revise traditional business models and to form new approaches to managing the modern bank.

Changes in the banking business model under the influence of the digitization of the economy are explored in the works of many foreign researchers, in particular Berghaus S., Back A. [2], Japparova I., Rupeika-Apoga R. [5], Lee I., Shin Y.J. [7], Nowiński W., Kozma M. [10], Yip A.W.H., Bocken N.M.P. [11] and others. However, the issues of assessing the 
effectiveness of the new banking business model in terms of environmental volatility and the impact of various threats remain under-researched.

\section{AIM}

The aim of the research is to investigate the impact of digitization on the choice of banking business model and the development of algorithm for estimating a bank's business model.

\section{RESULTS}

In terms of doing business, there is no single right way to manage a bank and make it profitable. The success of banking is the result of the proper performance of many small things and transactions. In particular, the components of a bank's success are good customer service, a combination of banking products, the use of marketing, a strong sales culture, good underwriting and profitable customer management. This is just a list of the most common components that can distinguish an average performing bank from a top-performing bank. Analyzing the types of business models used by banks, they can be summarized in five main categories, each with its own strengths and weaknesses.

Banks generally tend to cluster around one of five business models: lending, high leverage, investment, fee, margin. The quick summary and some characteristics of the most common models are shown in Table 1.

Table 1 - Characteristics of banking business models (based on [9])

\begin{tabular}{|l|c|c|c|}
\hline \multicolumn{1}{|c|}{ Model } & Main source of income & $\begin{array}{c}\text { Policy on other banking } \\
\text { activities }\end{array}$ & \multicolumn{1}{c|}{$\begin{array}{c}\text { Impact of financial crises and } \\
\text { imbalances }\end{array}$} \\
\hline Lending & $\begin{array}{c}\text { Net interest income, solid } \\
\text { deposits and loans }\end{array}$ & $\begin{array}{c}\text { Average margins, } \\
\text { minimum investment } \\
\text { portfolio }\end{array}$ & $\begin{array}{l}\text { "+" stable earnings; } \\
\text { "-" vulnerable to credit shocks }\end{array}$ \\
\hline High leverage & $\begin{array}{c}\text { Operating, deposit and } \\
\text { capital leverage; niche } \\
\text { customers and assets }\end{array}$ & $\begin{array}{c}\text { High fees on } \\
\text { specializing financial } \\
\text { services }\end{array}$ & $\begin{array}{l}\text { "+" often produce an above-average } \\
\text { performance; } \\
\text { "-" the widest volatility of earnings }\end{array}$ \\
\hline Fee & $\begin{array}{c}\text { Securitizations or pooled } \\
\text { sales of an asset class }\end{array}$ & $\begin{array}{c}\text { Cheap deposits } \\
\text { "+" excels in a stable or falling rate } \\
\text { environment; } \\
\text { "--" the largest standard deviation of } \\
\text { earnings }\end{array}$ \\
\hline Margin & $\begin{array}{c}\text { Fees generated through } \\
\text { operational risk }\end{array}$ & $\begin{array}{c}\text { Low leverage, limited } \\
\text { credit exposure }\end{array}$ & $\begin{array}{l}\text { "+" the smallest volatility of } \\
\text { earnings; } \\
\text { "--" high fixed costs or high barriers } \\
\text { to entry }\end{array}$ \\
\hline
\end{tabular}

Of course, most banks do not use "pure" business models, but hybrids of the above to generate profits in different ways. In addition, many banks have a business model that is simply not revealed by the statistical clustering of several performance variables that are key to the models under consideration. The advantage of having a clear business model is that it allows the bank's management to concentrate its resources in a particular area and improve over time. Not surprisingly, banks with a defined business model tend to outperform hybrid banks by a significant margin. This is confirmed by the fact that in the top 100 banks in the world, about $70 \%$ of banks are banks with one of the above business models.

If the bank's management understands what business model or mix of business models they are using, it helps to set the strategic direction and give a clearer picture of the risks. Compliance with the chosen business model in practice is a sign of a high-performing bank.

Smart banks understand their strengths and weaknesses and choose a model to best enhance their core competencies and environment. Business model knowledge gives bankers the ability to manage strategic and tactical decisions to take full advantage of their platform. 
Unfortunately, many banks do not choose their own initiative and do not use their model as a basis for strategic decisions. As a result, their actions often contradict their very balance sheet. A classic example is a bank that relies on income from loans and leverage, but still strives for yield over liquidity in its investment portfolio [9].

Nowadays a significant impact on the formation of banking business models is made by the digitalization. Over the last ten years, banking has slowly embraced the modern technology suite. FinTech has undoubtedly modernized the tired, internally oriented industry, but one crucial legacy aspect of its operation still remains. The two main components of the banking industry's business model, namely fee and float income, remain the main benchmarks for many top managers [8].

Commercial banks make money in two main ways: about $65 \%$ of their income is float income, and about $35 \%$ of their income is fee and commission income. Both of these revenue lines are contracting. For net interest income, margins between deposits and loans have been squeezed for most major currencies since the 2008 financial crisis. Base lending rates on GBP, USD and EUR have been fluctuating around zero as central banks have purchased huge amounts of government bonds in an effort to stimulate their economies. For net fee income, many competitive FinTech products have created competition and reduced prices. FinTechs are unbundling and re-doing all major traditional bank product offerings, so that fee income is much harder to capture [3, 4].

Nobody knows yet what will replace the current business model; since modern commercial banking began, it has remained relatively undisputed. However, there are currently three approaches in the FinTech ecosystem:

- the Financial Control Centre;

- Banking-as-a-Service;

- the Niche Bank.

The Financial Control Center refers to managing a current account and then adding additional products according to customer needs. This can be an external product menu, more deeply integrated partnerships, or a suite of internally developed products.

The approach of the Financial Control Center views banking products as modular and discrete, with the current account existing as a central "hub" to which all other products are connected.

In the abstract, the concept of the Financial Control Center is attractive. The menu of additional financial products for your current account is simple and elegant. In practice, this structure has not yet achieved significant customer acceptance [6].

Banking as-a-Service offers a plumbing of financial services - clearing access to the system, current accounts and debit cards - as a neatly consumable API for individual customer offers. It produces back-office banking features, allowing other businesses to grow on their basis to create new and exciting customer experiences. There are numerous FinTech companies that offer certain aspects of Banking-as-a-Service, such as:

- white-label accounts and domestic clearing access;

- white-label Direct Debit payments;

- off-the-shelf core banking systems;

- agent-access to e-money accounts;

- API access to bank account data.

Although outdated banks can technically offer these products themselves, their intertwining of front-office and back-office systems means that they lag behind in efficiency. They also have a much higher cost base and therefore would struggle for competitive prices [12].

Banking-as-a-Service has numerous counterparts in other industries. Just as AWS has developed a technical infrastructure for a whole generation of technology companies, Banking as-a-Service will relieve the strain of an existing financial infrastructure for new technologies.

The third approach is the Niche Bank. As technology and regulatory components become more accessible to the bank, it is possible to create banks which are targeted to specific 
demographics. The benefits of this are twofold. First, a Niche Bank can build its brand to strongly identify it with its target customers, rather than the awful general banking branding that is prevalent today. Second, it can build a set of features and partnerships that are very specific to these customers [1].

Niche banks are often provided by Banking-as-a-Service. Operations on a standardized infrastructure speed up time to market, reduce technical complexity and allow banks to focus on their unique offerings rather than technologies of banking [8].

Choosing a banking business model and following it when developing a banking strategy and tactics is one of the conditions for ensuring the success and stability of the bank. Most operating banks opt for traditional models because the business environment requires it. However, today, in the context of digitalization, banking business models can transform. This is especially true for Ukrainian banks. And since Ukraine is characterized by internal crises, banking business models should be aimed at minimizing internal risks.

Thus, an important component of banking management in an unstable environment is the analysis of the business model of the bank and its transformation in order to minimize the impact of possible negative effects of financial crises on the performance of the bank.

A feature of business model analysis is the comprehensive systematic assessment of financial information, strategy, short- and long-term plans, the results of which can be used to identify potential weaknesses in the business model and adjust the bank's plans.

We propose the following algorithm for the process of estimating a bank's business model (Figure 1).

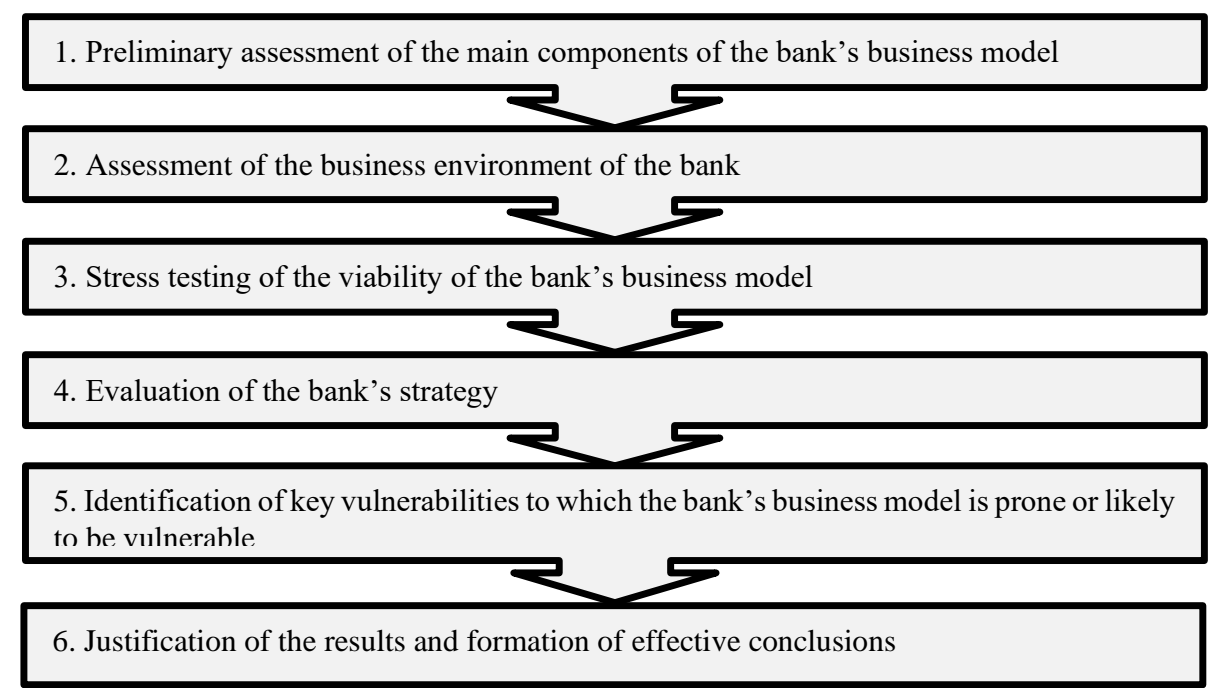

Figure 1 - Algorithm for estimating a bank's business model

The results of the business model analysis provide the management of the bank and regulatory authorities with an instrument for early identification of potentially hazardous risks or actions taken by the bank to generate current or future profits that could lead to increased crisis potential and ultimately bankruptcy.

If the results of the assessment lead to the conclusion that the business model is not viable or unstable, they should take timely preventive actions in accordance with the identified source of increasing crisis potential, even if the bank has not yet violated any applicable norms and regulations.

An indispensable part of the analysis is microeconomic stress testing. It should provide analysis and regulatory bodies with information about the conditions under which the bank's strategy and position may be most vulnerable. This information will allow to reconcile the 
strategy and position of the bank with the peculiarities of risks arising in its activity under the influence of exceptional but possible events (stressful situations, shocks).

Particular attention in stress testing at the micro level of the banking system should be given to markets and financial instruments that are characterized by the highest concentration of banking business (as in crisis situations these positions may be more difficult to balance) as well as to indicators of the global financial and economic environment. Also, stress tests help to identify potential problems in the context of high correlation between different risks.

In addition to analyzing the quantitative aspects of the bank's activities, there are also qualitative aspects to be analyzed, such as the quality of corporate governance and the effectiveness of risk management and control, including internal audit.

The results of such an assessment allow the bank's management to determine the reliability of its own risk management and control processes, which in turn will identify crisis zones. They also apply to banks that have inadequate corporate governance, risk management and control processes, early preventative measures, even if their sustainability is at an acceptable level. In doing so, the choice of instrument and time limits for the application of impact measures should be proportionate to the level of risk that the identified vulnerability poses to the bank or the system in whole.

\section{CONCLUSIONS}

An important component of banking management in an unstable environment is the analysis of the business model of the bank and its transformation in order to minimize the impact of possible negative effects of financial crises on the performance of the bank. Most operating banks opt for traditional models because the business environment requires it. However, maintaining the bank's competitiveness, enhancing its efficiency and resilience to financial imbalances is possible by building an innovative business model that takes into account the modern diffusion of information technology and the functioning of FinTech companies as an alternative to traditional banking business. There are currently three approaches to assimilating FinTech in banking: the Financial Control Center, Banking-as-aService, the Niche Bank. The choice of the banking business model and its transformation should be accompanied by an assessment of the bank's business model.

\section{АНОТАЦІЯ}

Посткризовий розвиток світової банківської системи, посилення ролі інформаційних технологій у всіх сферах $і$ галузях, зростаюча роль інновачійних ФІнТех посередників на банківському ринку спонукають менеджмент банків переглядати традичійні бізнес-моделі та формувати нові підходи до управління сучасним банком. У статті автори мали на меті дослідити вплив діджиталізачї на вибір моделі банківського бізнесу та розробити алгоритм очінки бізнес-моделі банку.

Традииійно банки обирають одну з n'яти бізнес-моделей: модель кредитування, модель левериджу, інвестиційну модель, комісійну модель або модель маржинального доходу. Більшість діючих банків вибирають традиційні моделі, оскільки изього вимагає бізнес-середовище. Однак зберегти конкурентоспроможність банку, підвишити його ефективність та стійкість до фінансових дисбалансів можливо лише шляхом побудови інноваційної бізнес-моделі, яка враховує сучасне поширення інформаційних технологій та функціонування ФінТех компаній як альтернативи традиційному банківському бізнесу. Незважаючи на те, шо на нинішньому етапі відсутнє однозначне бачення того, шо саме замінить існуючі банківські бізнес-моделі, на даний момент сформувалося три підходи до асиміляиіі ФінТех сектору у банківську діяльність: Центр фінансового контролю, Банк як иеентр фінансових послуг, Німевий банк. Вибір моделі банківського бізнесу та ї̈ трансформачія повинні супроводжуватися очінкою бізнес-моделі банку.

Таким чином, важливою складовою банківського менеджменту в нестабільному середовищі є аналіз ділової моделі банку та їі трансформація з метою мінімізації впливу можливих негативних наслідків фінансових криз на результати діяльності банку. У статті запропоновано алгоритм оцінки бізнес-моделі банку, який включає 6 етапів: попередня очінка основних складових бізнес-моделі банку; оцінка ділового середовища банку; стрес-тестування життєздатності бізнес-моделі банку; оцінка стратегії банку; виявлення ключових уразливих ситуачій, до яких бізнес-модель банку схильна або може бути вразливою; та обтрунтування результатів і формування ефективних висновків.

Ключові слова: банки, модель банківського бізнесу, банківський менеджмент, цифрова економіка, інновачійна бізнес-модель.

\section{REFERENCES}

1. Banking on the Future: Vision 2020. [Electronic resource] // Cll-Deloitte. - 2015. - Access mode: https://www2.deloitte.com/content/dam/Deloitte/in/Documents/financial-services/in-fs-deloitte-bankingcolloquium-thoughtpaper-cii.pdf 
2. Berghaus S., Back A. Stages in Digital Business Transformation: Results of an Empirical Maturity Study [Electronic resource] // MCIS 2016 Proceedings. - 2016. - http://aisel.aisnet.org/mcis2016/22

3. Finnegan M. How technology will transform banking in 2016: Blockchain, digital challengers and IoT [Electronic resource]. - 2016. - Access mode: http://www.computerworlduk.com/it-business/how-technology-willtransform-banking-in-2016-blockchain-digital-banks-iot-3631853/

4. How mobile is transforming retail banking: Redefining banking to survive and thrive in a digital world [Electronic resource] // Economist Intelligence Unit. - 2014. - Access mode: http://www.sap.com/bin/sapcom/en_us/downloadasset.2014-12-dec-05-18.how-mobile-is-tansforming-retailbanking-redefining-banking-to-survive-and-thrive-in-a-digitalworld-pdf.bypassReg.html

5. Japparova I., Rupeika-Apoga R. Banking business models of the digital future: The case of Latvia // European Research Studies Journal. - 2017. - Vol. 20. - P. 864-878.

6. Lautenschläger S. Digital native? Fintechs and the future of banking [Electronic resource]. - 2017. - Access mode: https://www.bankingsupervision.europa.eu/press/speeches/date/2017/html/se1703271.en.html

7.Lee I., Shin Y.J. Fintech: Ecosystem, business models, investment decisions, and challenges [Electronic resource] // Business Horizons. - 2018. - Vol. 61. - Issue 1. - P. 35-46. - Access mode: https://doi.org/10.1016/j.bushor.2017.09.003

8. Mitchell O. The new business models of banking [Electronic resource] // FinTech Futures. - March 2019. Access mode: https://www.fintechfutures.com/2019/03/the-new-business-models-of-banking/

9. Nichols C. The Five Business Models of Banking [Electronic resource] // CenterState Bank Correspondent Division. - January 2019. - Access mode: https://csbcorrespondent.com/blog/five-business-models-banking

10. Nowiński W., Kozma M. How Can Blockchain Technology Disrupt Existing Business Models? // Entrepreneurial Business and Economics Review. - 2017. - Vol. 5(3). - P. 173-188.

11. Yip A.W.H., Bocken N.M.P. Sustainable business model archetypes for the banking industry [Electronic resource] // Journal of Cleaner Production. - 2018. - Vol. 174. - P. 150-169. - Access mode https://doi.org/10.1016/j.jclepro.2017.10.190

12. Zachariadis M., Ozcan P. The API Economy and Digital Transformation in Financial Services: The Case of Open Banking [Electronic resource] // SWIFT Institute Working Paper. - June 15, 2017. - No. 2016-001. Access mode: https://ssrn.com/abstract $=2975199$ 